\title{
オプティカル・グラスファイバーの 医学面における応用について
}

永岛苗れではただいまか ら，本日のテーマである「オプ テイカル・グラスファイバーの 医学面への忘用について」の座 談会を始めたいと思います。

最近盛んに「フアイバー・才

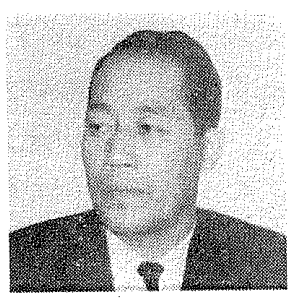
プティクス」ということがいわれて捛ります。この制 品のオプティカル・グラスファイバーが医科器械と連 係をもちまして，治療上に打きま子検查，测定，そし て診断にたい人ん役立っていることはご承知の通りで ございます．当学会の編集委員会におきましても，こ のテーマがたいいん扔もしろいので,きょらお集まり くださいました皆様方に，いろいらな传度から㮝討を 加えていただいて，将来に角えて行きたい，こういら

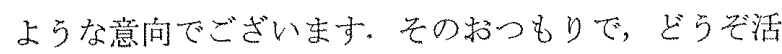
発なご発言をいただきたいと旺います。

グラスファイバーができましたのはずいぶん子るい ことだそらで，その源古代にすでにつくられたとい らことを聞いて扔ります。ちるんそのこるそれが物 の役に立ったとは思えませんけれども，その゙後開発が 進められまして，これが工業化され，工業的な面に使 われたといらのは近及百年趉ないんしゃないかと思 います、これと平行してか，あるいは別途にか存しま せんが，そのファイバーのオプティカルな面が開発さ れまして，きょうの座談会のテ一マに㐌るような，医 学面へも用いられるようになったというわけでござい ます.この医科器械学雑誌学ご覧くださる方は，打医 者さんあり，業者あり，またテクニシャン交り，各階 層の方が大勢見て拈られまして，てらいら方々は，グ ラスファイバー，絮いはオプティカル・グラスファ イバーがどらいらものであるかといらよらな概念は括

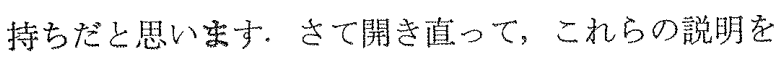
求められると，果してどれだけの方がそれに就して正 確な答えができるか，疑問だと思います，きょらこれ からいるいるとお話しが出る上に执いても，このグラ スファイバーやオプディカル・グラスファイバーの歴 史定知り，どういうものであるかといらこと交解明す るのも，たいんん意義のあることだと思います，きよ らの座談会の第一といたしまして，これらの今日まで の発達の経緯を㧍話ししていただきたい。

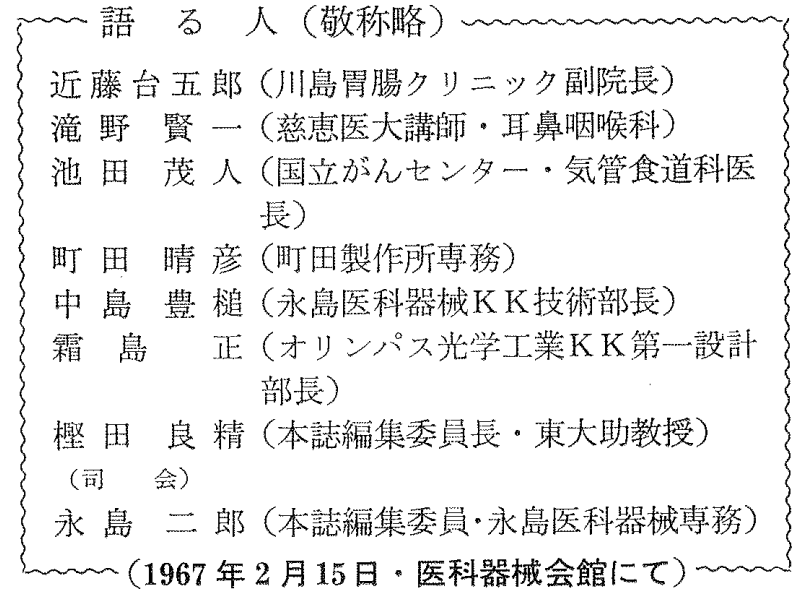

きょうはガラス繊維の専門メ一カーの方は格招きい たしておりませんが，㔬いオリンパスの霜息さんがお 見えでいらっしやいますので，霜息さん，まずその辺 から括ししていたたきたいし思いなす。

\section{理論は 1926 年，実用は 60 年ごろ}

霜島 最近使われて扔りますファイバースコープと いらのは，私もちよっと調べてみたんですけれども， 原理は割り合いふるくから考えられているよらです。 1926,7 年ごるに特許がもら欧米であらわれ始めてい るよらでございます、したがいまして，ファイバース コープそのものの特許といらのは，いむはもら全然問 題はないわけなんです。しかし，何でもこういら新し い原理のものはをらですけれども，だいたい最初誰加 が考えて，それから10年とか20年とかほったらかしに されることが多く，誰もそのほんとうのよさがわから

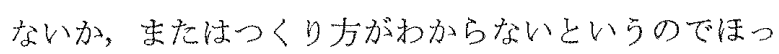
たらかしにして置いて，奉際それが実用になるのはだ いぶんあとになるわけです. オプティカル・ファイバ 一の場合も奏用になり出したのは1950年末ごろ，つ乎 り1960年に近いころアメリカで始まったよらで女りま t.

池田たしか1926年だと思い未すけれども，オラ ンダでグラスファイバーの理論がはじまったといらこ とを私読んだことがございすす。

霜島 製造がですか。

池田 製造といらよりも，その理論ですね。考え方 が始まったと思います。 
霜岛 その後, アメリカでその実用化が行なわれた といってもいいんじゃないかと思います. 1960年近く になって，これはどういら方面に実用化されたかとい えば,ややはり医学および軍事用の目的じゃないかと 思うのです．その後日本で研究が内密のらちにはじ められ，数年たってからつくられるようになりまし た.

ファイバー・スコープという形になって使用され始 めたのは，日本においては 4,5 年前ということになっ ていると思います。

それから製造法でございますが，要するにナイロン やガラスの繊維を引くような原理にしたがっているわ けです.ごく大略に申しあげますと，1.6ぐらいの屈 折率のフリントガラス棒のまわりに，1.5ぐらいの屈 折率のガラスを最初にくっつけて置きます。 これ法か なり太いものですが，それをちょうど紪維をひくよう な原理によりまして非常に細く引き，数十ミクロンま でに引っぱりのばします，後にこの細いファイバーを 規則正しく並べます，その引き方とか，あるいは重权 方もいろいろな方法がございまして，これは各社がみ な秘密にしているょうですしかし，つくった物の断 面を頙微鏡で抬大してみると，専門家ならば，これは どういう方法でっくったかということ注すぐわかるよ らです。

\section{初めてガストロカメラに応用}

永岛 ありがとうございました。これは私よくわか らないんですが，普通のグラスファイバー，いわゆる ファイバーには寸べて光学的な要素を持っているとい うことがいえるんですか．それとも別個にこれは考え られたものですか. ファイバー1本1本ですか.

霜島 1 本 1 本に，やはりある規格が必要になるわ けです。たとえば，ある屈折率とか，それから透明度 がいいものだとか，表面がきずがないとかいら非常に らるさい性質が要求されます，それがたくさん重なっ て，一つの性能を発揮するようになるわけです。

永岛 いや，いま伺ったのは，たとえば，このガラ 又纎維は綿状になったものや，その他いろいろとあり ますが，そんなものじややはりオプティカルな用途に は役立たないわけでしょう，まるっきり。

霜島 そらです，綿状みたいになっていると困りま して，ある大きさに巻いて置くとか，そらいう状態に 最初からして置きまして，それを規則正しく積み重权 たり，束㸚たりするわけです。

永岛 だいたい，ただいま伺い生して，どのような ふらにしてっくられるか，こういったものであるとい うことがわかったわけでございます.これでどうなん
でしょうか, 日本で初めてこれが医科器械に忘用され たというのは，私はガストロカメラだというふらに思 い込んでおるんですが.

霜岛 ガストロカメラに観察鏡としてファイバース コープが取り付けられたのが最初のようです．ほぼ同 じころ外部カメラ式の，いわゆるファイバー・ガスト ロスコープができました.

なおガストロカメラといらのは, 皆さんご承知だと 思いますが，カメラを胃の中に突込む考え方のもの で, ファイバー・ガストロスコープといらのは, カメ ラを身体の外において撮影するという考え方です。し たがって，写真そのものは前者の方がすぐれているの は当然です. 後者のファイバー・ガストロスコープは アメリカで最初につくられ, 次に日本の 1,2 のメ一カ 一で売り出されました。

永岛つまり，ライト・ガイドとして用いるのと，

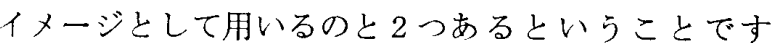
㱛.

霜岛 ライト・ガイドというのは光りを通すだけの ファイバースコープのことでございまして，それはま た別でございます、いまは一応光学像を伝えるイメー ジ・ガイドといいますか，イメージ・ファイバーとい いますか，そらいうものの話しになっております。 ラ イト・ガイドというのは単に照明の道具でありまし て，物を見る道具ではないわけです，ただいま申しあ げをした胃用の可撓性内視鏡にはライト・ガイドは普 通は用いられませ九。

永岛 そうです权，近藤先生はそういった胃カメ ラ,こういったものを，ずいぶん前からご使用になっ ていられますので…....

近藤 僕は胃カメラは，あまりやったことがないん です、いま永島さんがおっしやったよらに，胃鏡のほ らを主にやっておるんです.

永島 胃鏡もいま霜島さんのお話しですと，やはり このオプティカル・ファイバーを使ってやりました, おそらく初めての器械だというふうにも思えるんです が，どのようにしてそれを㛹いになったか，その辺 から…...

近藤 どうでしょうか，霜島さん，医学の分野では 胃鏡に一番早くはいったわけなんでしょうかね. 他の 分野のことは，私は一寸も知りませんが.......

霜島 昔, 胃鏡があったわけです斌。それから，そ れが硬くて困るといらのでファイバー化されたといい ますか，レンズを使う胃鏡をやめてしまって，ファイ バー・スコープを使う胃鏡にしたのがアメリカで，そ れが一番早いと思います。

近藤 その前には他の分野(たとえば工科方面など) 
では使われていなかったんでしょうか。

霜島 ファイバー・スコープは商品としては使われ ていなかったと思いますささっき䒤しあげあしたよう に，アメリカで1960年らょっと前にいるいる実験的に やられていた事実はありますが，これはよくわかりま せんが，研究所の中の研究用亡か，西るいは軍事用に 使われていたと思われます，商品としては，やはり医 学用の内視鏡がはじめてじないかと思いまする。

近藤そうすると，アメリカン・チスト・スコープ。 カンパニーのあれが一番初めなんですね。

霜島，私はそうじゃないかと思います。

近藤をちですか，商品としてはね。

霜島 少なくとも，われわれの目に子れる商品とし て初めてだららと思います。

近藤 そうすると，墑品としてはアメリカン・チス ト・スコープ・カンパニーでっくった，ファイバー・ ガストロスコープが初めだしいらことでだいたい良い わけですね.

霜島 ええ。それが日本では，いま近藤先生がおつ

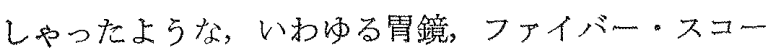
プといいます加，それと，それからオリンパス加昔か らやっていた胃カメラです福，これにファイバー・ス コープをくっつけた，いわゆるファイバー・スコープ 付き胃力メラというのと，同じような時期に 2 種類が 発表されたのだと思います。

\section{イメージ・ガイドは日本とアメリカ}

永島 近藤先生は，その胃鏡索盛んに当初括使いに なられたわけですが，やはりその光学緎維をつけた 器械といらのは，非常な效果があったわけなんです 力x。

近藤 私は，何年前になりま すか，眻鏡を最初に使わしても らったわけです，以前から軟性 胃鏡といっても一部分が硬い胃 鏡の、これには長所もあります けれども，短所といいますか，

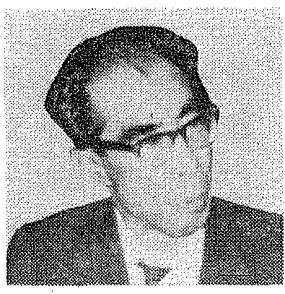
そらいらことを身にしみて経験していたものですか ら、ファイバー霄鏡とは，これはいいものができた こそういら感しを受けたわけなんです。

もち万ん，初めにできたファイバー胃鏡にも，弱点 はありました．徉って日本でどらいらふらにその弱点 をカバーして行くか，改良して行くかといらことで， グループをつくっていろいろやっで行ったわけなんで 于े.

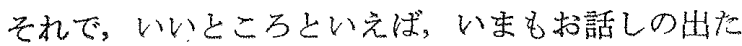
非常に扱いやすいといいますか，といらことは逆にい
5と，検查を受ける患者さんが非常に楽だということ 前の胃鏡に比べて，てれが一つです，それから，前のレ ンズを使ったものよりも光りのロスが少ないですね。 ですから胃の中䘮同じ光度で明るくしたとすれば，フ アイバー胃鏡の像は軟性胃鏡のそれに較べてぐっと明 るい，従って目で見て見やすい。また写真も撮り易く なったわけです，弱点としては，レンズ系を用いた軟 性胃鏡の像にくらべてファイバー胃鏡では，その像 の輪かくがでこぼこになりぼやけていることでし た。そういうことが大きな弱点としてあったわけです が，それを日本でレンズ系安使った胃鏡と同じぐらい なシャープさのものが最近ようやくできたといえると 思います。

永島 その解像力の問題とか，それからファイバー の製造過程によるファイバーそのものの良否というの

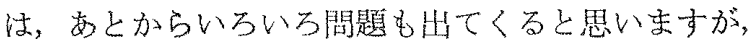
非常にたいしたものができたといら点について，も5 少し和っしやっていただきたいと思います。どういう 点でとくに….

近藤 いまつくっているのは，アメリカと日本だけ じやありませんかささっお話しがありました，ラ イト・ガイドだけ究利用した㥜鏡に限って申します とドイツあたりでもでさております。ししイメー ジを目のほらへ持ってくるという純然たるフォイバー 胃鏡亡いらものはアメリカと日本だけです。いろいる な意見の相違はあると思いますけれども，目で見てし っかりした像をつかまえるといらことが，われわれ医 者としては一僠大切なことだと思らのです。そらいら 意味で，イメージをくっきりさせるといいますか，そ れから色む，害際蜀の中はよく変わりますから，とれ がほんとの色かといらことはわからないわけですけれ ども，とにかく目で見えた色を，そのままわれわれの 常識で頭の中にある胃の粘膜の色と同しような色が出 てくるといらことですね. そらいらことも大切なこと であります，そらいら雨方の意味で，アメリカのむの と日本のいまのものと比べれば，それはも5日本のほ らが絶刘にいいということはいえると思います。

永岛 先汪どの初話しのなかに, 研究会をつくった とおっしやいましたが，それが現在の内視鏡学会の始 めでございますか。るそれとは全然……

霜島 ファイバー・スコ一プ研究会というのは私も 聞いて和りませんが，ただ，内視鏡学会のときにシン ポジウムとか研究全的な催しが行なわれているようで す外。この間む，私は出ませんでしたが，町田さんは 招出になったんじゃないかと思います。

滰野 学会でファイバー・スコープについてのシン ポジウムその他が大きく採りあげられたのは，一昨年 
の内視鏡学会だと思うのですがね.

\section{耳鼻・気管食道科領域での推移}

永岛近藤先生は当初そらいった内視鏡を招使いに なって，いろいろ経験をなさったわけです．現在はこ れらO.F.G. 在使った器械がたくさんできていると思 らのです，池田先生，滝野先生は，食道鏡之か，その 他の内視鏡類を盛んに研究しておつくりになっておら れますが，現在はいったいどらいうよらなものがござ い专すか。

滝野 話しの順序としまし て，私がフォイバー・スコープ を使い出した理由から申しあげ たら，一番はっきりするかと思 らのです。私ども内視鏡を専門 とする者は，内視鏡下に見た所

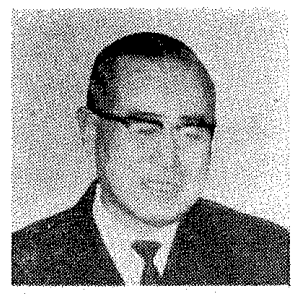
見を記録して，それを日常臨床に役立てるのですが， こういう所見があったといらことを自分の主観で記録 いたします，えをかいて，といらよらなことになりま すが，見たままを記録するといらことが必要です。自 分で見て，自分で判断し記録するのでは，主観がどう しても強く出てしまって, 間違っているかもしれませ ん. しかし所見を写真に撮っておけば，これはも5一 番よいわけです。それで写真を撮ららといら企てが子 るくから耳鼻科窅域, 気管食道科の領域では行なかれ てきたわけです，その始まりは1936年ですか，野口先 生が手をつけられ，1939年には東大の切替教授がスト 口ボで㬋頭の写真を撮っておられます，外国ではもっ と以前からやっておりますけれども, ての方式は值達 鏡の外にカメラを置いておいて，直達鏡管を通して内 部を撮るといら方法 Open tube system と，そのテ レスコープに写真機をつないで撮る Telescope 方式の 2 つの方式で発展してきたわけです.

わが国では，1950年〜52年にかけて白黒映画で撮れ るよらになり，何とか見られるようになってきまし た. 日本医大の橋本教授が非常に努力定され，学会に も発表されて㧍ります。しかしそういうような写真な り，あるいは映画なりを見て，また実際にわれわれが それを利用する立場になって，一番欲しいと思うの は，もっと鮮明な写真が撮れないかといらことです。 鮮明な写真を撮るためには，どうしても局所の照明孛 もっ亡明るくしなければならない，明るくならんか上 いらことでメーカーを責め立てて，いるいるつくって むらら．ところが電球照明では，5んと明るくすれば 熱老带びる，また先端照明で，小さい電球で局所を照 らすとすれば，電球そのものに制限があるといらこと で，何とか明るく照らす方法がないものかと苦心して
おったわけです．私は1960年から町田製作所のテレス コープを使って写真を撮っていたのですが，一応従 来の写真と比へてて明るく，またある程度の鮮明さを持 った像が撮れるよらになったものですから，それを学 会にその当時から発表して拉ります。 それでもやっぱ りまだまだこまかい点は写し出されていない，そこ でこここにおられる町田晴彦さんをせめまして，何と か明るく局所を照らす方法はないかといらことで，店 まで押しかけて行ってこんな方法はどらだ，ああ だ，こうだといって議論在したこともあるんです、私 の当時の構想として，テレスコープのまわり，対物レ ンズのまわりから局所を照らすと，もっと光度を堌せ るのではないかといらことだったんです．1962年にフ アイバー・オプティクスが手に入り，それでテレスコ 一プのまわりから照明をしてみようということにな り，いろいろ苦心されてできたのが，1963年の1月 で，それが直径 $6 \mathrm{~mm}$, 長さ $45 \mathrm{~cm}$ の気管支用のテレ スコープです. ファイバー・オプティクスをライト・ ガイドとして用い，従来のテレスコープのレンズ采で 局所老みる。これは直達鏡下に用いるのですから， Flexibleでなくてもよい，これで従来にない非常な明 るさで視野をつかめ，力ラ一写真，映画も撮れる．ち ょうどそのころ，小野譲先生が宿題報告に食道の映画 が必要となり，町田さんのほうから私に，「できまし たが，まず小野先生に使っていただいて，よろしらご ざいますか」といら括話しがあり，「どうぞ」という ことで，池田先生がそれで食道の映画を撮られた。 そ の後, 私はそのファイバー・スコープを日常臨床に使 ってみたんですけれども，Fiberoptics が黄色完おび ていて色がよくない，そのらちに「もっといいFiberoptics がはいったから…‥」といらのでつくってもら

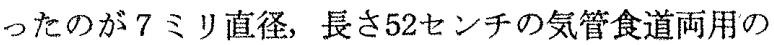
ものです，それで盛んに気管支および食道の映画を撮 った。またこの方式沖鼻科領域にも忘用できるんし やないかということで，耳鼻内視鏡をつくりました。 これは太さ值径 $4 \mathrm{~mm} \times 5 \mathrm{~mm}$ の楕円形で, 有效長 20 センチのものですが，それをつくっていただき，実際 に鼓膜や鼻腔内の写真や, $16 \mathrm{~mm}$ カラー映画も撮り, 気管食道の映画と共に，1963年の秋の学会に発表しま した. その翌年, 1964年 2 月には汎アメリカの気管食道 科学会にも発表したわけです.

更に咽頭掞よび喉頭の映画む撮れるんじやないかと いらことで工夫しまして，先が $6 \mathrm{~mm}$ 直径, 長さ $30 \mathrm{~cm}$ の咽喉頭鏡をつくり，咽頭および喉頭を見るようにし た. 更に太さ冒径 $8 \mathrm{~mm}$ の側視用をつくり，座った位 置で，間接喉頭鏡で見ると同じような位置で喉頭が見 える喉頭側視鏡もつくりました。 
また声帯の前連合の部分もよく見えるように工夫さ れた，群大の石井教授による声帯鏡がつくられるとい らことで，耳鼻咽喉科，気管食道科領域においては， ファイバー・オプティクスをライト・ガイドとして使 った Fiberscope が盛んにつかわれてきたわけです. その後 Fiberoptics の一番の特徽であるフレキシブル な点と, イメージ・ガイドとしての性能をいかして， お隣りの池田先生がそれを実際に使われるようにな った.こういうことでしょうね.

\section{生体の記録から機能分析の方向}

永島 ずいぶんいろいろ詳しいことをお話しいただ きましてありがとうございました。

たしかに耳鼻科などですと，現在やはりライト・ガ イドとして用いるのがいいといらよらな拉話しもあり ました，たしかに細いですから，完全な像を送るとい らことはなかなかむずかしいことだと思うのですが， 池田先生專門の拈立場加ら，やはり気管支鏡，こうい ったものを盛んにお使いになると思いますが，その非 常にいいといらような面からいらと，どういうとこる でございますか.

池田 いま私のいいたいと思 っていたことは，だいたい滝野 先生がいってくださいましたか ら，私のいらことはほとんどな いんで.......（笑）ただ補足さ せていただければ，たまたまち

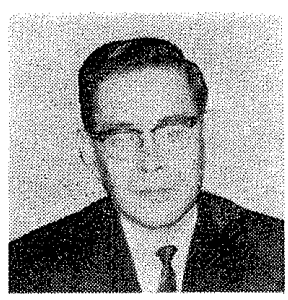
上らど気管支鏡によってより良い診断をしようという グループが，たとえば，千葉大の㻕江先生とか私とか が持っていた希望と合致して，現在のようなライト。 ガイドによる気管支鏡といらものができたんだという こと、それがさらに現在のリジットスタイル，すな わち真直ぐな硬性の気管支鏡，食道鏡というのに完成 して行ったといら尔うに感じて拉ります。こ机は先ほ ど滝野先生が扔っしゃったように，中を見るだけでは なくて，記録をとどめるということの意味が非常に強 かったんじゃないか.

で，私のことを申させていただきますと，私はそも そも中の記録を撮るといら意味に招いて，映画という ことに非常に関心を持っていたわけなんです，その前 からいろいると中の映画を撮るといらこと。これは， 最近ことにガストロ・ファイバースコープで非常に盛 んになりつつある一つの現象だと思いますが，映画を 撮って記録をとどめる．分析をするということを非常 に関心を持っていたわけですが，それを行なうには， このライト・ガイドによる硬性の気管支鏡といらもの が非常に役立った：それから，それの進歩に少しばか
り貢献することができたんじゃないかといら子らに感 じて括ります、これ私が，い主前にいる町田晴彦 君をさんざん責め晾げまて，決して満足していな い，不満足の状態でございますれども，まだまだ要望 をしょっちゅらいっているわけでございます，その要 望といらのは，今後記録をとどめるということだけで はなくて，さらに生体の機能を分析するといら方向， これは研究的な力向があると思いますが，こ5いら方 向にまで持って行かな⿰れればならないと思います。す なわちそれ者りら少しやさしくいえば，記録にとどめ るならば 8 駒の写真, 8 駒の映画でもいいし，12駒の 写真でもよろしいかと思います。しかし1秒間に24駒 の映画が撮机るよらなれば，な扔一層生体の見てき たそのままの状態を写し出して再現させることができ るわけですから，より一層正確な診断の面にも役立ち ますし，教育の面にも役立つと思いますし，これが記 録になると思います。しかし，ひとたびその動きを分 析したいといら面になって京いりますと，24駒ではど らしてもあき足りない。これがまだまだ不満足な点に はいってくるのではないかと思います。

\section{要求される,より細く}

いま私が最も好きである映画の面から，内視鏡とい うものをいわせていただいたわけなんでございます が，現在の硬性気管支鏡というものが，これはライト。 ガイドによって光りを送るといら，先ほどから滝野先 生が㧍っしゃったような意味でのものでは非常によく 進歩したと思います，それと異なった内視鏡として は，イメージをグラスファイバーで伝える，ガス卜 ロ・ファイバースコープの行き方，これは先端に電球 があってイメージをグラスファイバーで伝えるといら 方向であったと思います。

そこで，だんだん両方を満足させて行かなければな らないのではないかといら方向にきたわけなんです。 すなわちライト・ガイドもファイバーで使う. イメー ジもファイバーで使う。しかもこれはもらガストロ。 ファイバースコープで一部できており安すし，それか ら一昨年ぐらい加ら食道ファイバースコープといらよ らなものでもできつつありますけれども，これをさら に紐くするといらことが必要になってきたわけでござ います。

これはいったいなぜかといいますと，気管支鏡とい らのは，ご承知の通り，気管支の中に突込むわけで すが，どうしてむ見ることのできない範囲があるわけ です。すなわち, 硬性気管支鏡の盲点活両側の上葉で すが，これをできるだけ見るためには，先端が曲がっ てこなければならないといら当然の結果についたわけ 
です，それには，気管の中に太いむのを入れると窒息 といらことを起こす，患者の苦痛も大きい，そういら ためにらんと細くして，しかも先端が曲がるといら非 常にむずかしい要望が出てきたわけで，これが何とか ならないかということを考えまして，それを種々機械 メーカーの方に括話ししたわけです，それでこれは一 昨年になりますか，昭和40年の春だと思いましたが， 私がこういら構想を持っているといらことを町田さん のほらへ話しまして，それで作九ないかといらふらな ことを話し，そのあとにこらいういくつかの，たしか 7 項目だと思いましたけれども，箇条書きにしまし て, こういら考え方の下にっくってほしいというふう な要求を扔願いしたわけでございます，すなわち，イ メージもライト・ガイドもグラスファイバーを使ら気 管支鏡，太さは 4 ミリ以下にする，この 4 ミリは今で もまだかな元ていただいていないむりなオーダをし たわけです，一応私のほうでは，それを計算的に出し てやったっもりです，そらいらオーダを出してやって 行きその後オリンパスにもその話しを持ってまいり まして，まだもら一社打願いしたところもあるんでご ざいますが，そうしてさらに細いものをつくっていた だこうというふらなことをやりだしたのが現状でござ います。

永島 どらむいろいろありがとうございました。

近藤 だいたい最近の映画は16駒まで行っているわ けですね.これをもう少し多くするというわけですが ね.

それから栓田さんがファイバースコープに初めから 興味を持っておられました，以前，当時工学部教授で あった安藤さんといら方のところへ相談に行きまし て，ファイバースコープをつくってもらったことがあ りますが，5-10センチくらいの長さまでは日本の技 術でできる.イメージは非常にぼんやりしていました けれども.

永岛 ちょっと心細いですね。

樫田 5 センチ位の長さでし たね.ガラスの棒みたいなもの でね。それは私も見本を自たで 寸

私は，ちょうどその雑誌を出 して, アメリカー行きまして向

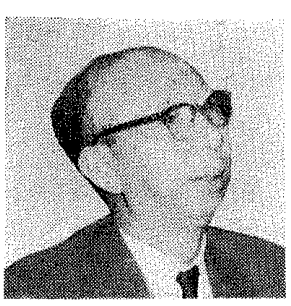
こらでライトガイドとかガストロスコープとか見たも のですから，これは早く日本に紹介しなければいけな いと思って出しただけです.

近藤 高木さんも一緒に行ってね. 日本のフォイバ ースコープの歴史に一役買って扔られるのですよ.

\section{国産イメージ・ファイバー試作の苦心}

永島 どうもありがとうございました，後ほど摼田 先生に抒伺いします。

きょうは何か町田デーみたいになってしまいました が，さっき座談会が始まる前に「きょうは怒られる側 に回るんだ」と町田さんはいっておられましたけれど も，この怒られることがかえってまた町田さんのプラ スになることだと思います，ご同慶に堪えません，… …(笑)

それでどうですか，町田さん，これらをつくるのに 相当前から苦心をして研究なさって, 先生方の要望に こたえておら扎るといらことを聞いておりますが，お 差しつかえない範囲で，これをつくる苦心といらょう なものを，一つ順序立てて拉話しをしていただきたい と思います。

町田 最初このイメージとい らものが,とてもらちなんかで 扱えるしろものでないというの で, 光りを後から持って行こ ら、それがまず最初の考えだっ たのですが，何年前だか思い出

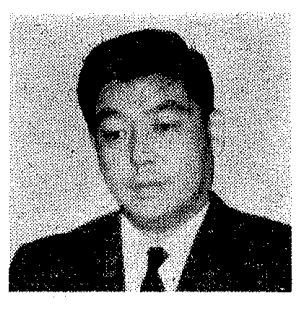
せませんが，ちょうどアメリカのイメージ・コンジッ 卜を見る機会を得まして，たしか $2 ミ リ$ 角だったと思

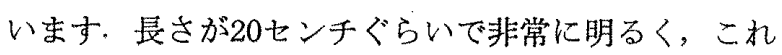
は非常にいいものだと思っても, グラスファイバー 自体はどらしても手にはいらないものですから，その 前段階として，まず石英の棒で送ろうじゃないかとい うことになりました。ところがいまでもフランスあた りのエンド・スコープはアクリルとか, 石英の棒を使 っているらしいのですけれども，それを付けますと， どうも扁平なかっこうになってくる．それを丸くする のにはどうしたらいいか. 石英の棒をガスで細く引張 ったものをそのまま使ったのでは, 光りがこなくなっ てしまう，それで石英の棒を磨きまして，まずコル ポマイクロスコープを陚作してみました，そのらちに 滝野先生のほうから，何とか細い空間に入れろという 拉話しがきまして，ちょうどそのころに日本でもオプ チカル・グラスファイバーができるようになりました ので，それを引込んで一応光りを送れるものができた のですが，その頃の系は20センチぐらいで黄色がつい てくる、ガラスの吸収で起こる色ですから，補整フィ ルターです, 完全には色を補整することが不可能で す. 当社では, 系の開発と供給を日本硝子緎維さんに ご依頼している関係上，そちらの技術の方に「何とか 色を白くしてくれ」とお願いしまして，半年ぐらいた ってからだいぶん色が白くなってきまして，体の中の 
映画が一応良い色に写るようになったわけです．その 頃に八ーショヴィッッのファイバースコープが日本に はいってきたのですが，当時当社で作られていた硬性 胃鏡と，それから幽門部を見る時に先端部が屈折する 屈折胃鏡は, ファイバースコープに比べて暗いし, 使 用時の困難さがあるので，これは将来完全にファイバ ースコープに置きかえられるものだと思いました，そ のときの明るさを調へてててびっくりしたことは, 硬 性胃鏡の16倍もあり，先端に付いている電球の明るさ で充分写真の掫れることです，ただ，イメージ自体に 黄色い色がついているので, 青フィルターのついた電 球をつくりまして，一応先生方のご便宜を図っていた のですが，そのころから当社でもイメージ・ファイバ 一をつくり出しまして，あれは1963年ですか，鹿児島 の学会にようやく試作品を出品することができまし た. そのときのものは，人の顔がただ顔らしいという 程度のもので, 翌年 3 月ごろから市場に出したのです が，いまから見ますと，だいたい 6 万 5 千本のイメー ジで，150〜160本のきれがありました．それから， 並びのほうもまだまだ問題がありましたが，それも徐 タに向上しまして，最近ではだいたい 40 本以上， 0.01 \%ぐらいのものは不良品とされている段階です.

\section{解像カと緀維の太さの調整に苦労}

その後, 先生方からは「細いもの」といらご要求が 多くなりました.ところが，グラスファイバーは緗く なってまいりますと，まともに取り扱えないしろもの で, 置くにしても手で持つにしても軽すぎて, 上にあ がって行くような状態でして，それもただ両手でつか めば切れてしまうといらくらい弱いものです. それで 池田先生のほうからお話しがあったときに，私はだい たい中を見るのには 4 万本以上なければ見えないとい ら考えを持っているのですが，先生は「もう少し少な くても，何しろ見えればいいよ」という話しで何とか つくってみたのですけれども，意外によく見えたの で......

永岛 見えればいいといらのはどらいらことです 加.

町田 マーゲンの場合は, 距離が10センチぐらい離 れて，胃鏡の J I S にもあるように， 0.5 ミリ以下の ものが一応見えなければ意味がないんじゃないか. そ こまで解像力を結局上げなければ，ファイバースコー プとしては全然役に立たないのではないかと考えまし て，2ミリぐらいのものでしたらレントダンでも出て おるわけですから，やっぱり中をのぞくためには，解 像力を 0.5 ミリ以下までもって行かなければ市販でき ないということです，ところが，気管支鏡の場合なん
かですと，胃袋よりもずうっと距離が近いですし，先 生の撮られた写真を見ても，なかなかいいものが多い といら感じがするのです. そこで最初の1本をつくり しまたら，一応曲がればいいといらお話しだったので すが，それができあがって先生がのぞかれますと，今 度は脇が見たい（笑） 脇を見ていると，今度またそ の奥が.......

たしかに気管支といらのは，見ておりますとトンネ ルの枝分かれのようで，見たいのは人情だろらとおも いまして，それから何としても奥まで行こうと作り始 めたのですが，頭がくもったりした場合の洗浄だと か, 麻酔だとか, 細胞採取器だとか, 種々付属します ので，現在 5 ミリ以下にはまだなっておらないといら ところです.

\section{海外で反響を呼んだ日本製}

永岛 たいへんな苦労をしていろいろ研究をなさっ ておられるわけですが，町田さんの所では，いわゆる 名人芸的な手技によりまして，ファイバーを管の中に 入れるといらよらな技術もあるわけですが，そういっ た点は…....

町田 これは最初のうちはたい一んでした．切れま すと, 手だろらと, 顔だろらと, 背中だろらと, どこ にでも刺さるのです，そのために雨合羽を着まして， くつ下も通ってしまうので, ビニール袋を足にはき， 頸にはタオルを 5 枚ぐらい巻く，そのままでは寝られ ませんで，お風呂へはいり，まず糸をおとす，そんな ことをしながら作りあげることだけを目標に追いかけ たわけです，そのらちいっの間にか系のほうがおとな しくなりまして，こっちの思うようになったといらよ らな状態です。

永岛 ファイバーをならしたんですね.

町田 そういうことです.

滰野そのご苦労は初めて聞きました. 雨合羽など 着てやっていると思わなかったから，もっともっとと いってね. 一番先にっくったのはアメリカ製の Fiber optics をつかったのではないですか. 私が向こらへ持 って行ったのは.

町田 あれは日本製なんです。

潼野 それでは，私は向こ5でらそついてきちゃっ たのですね. 第 9 回の沉アメリカン気管, 食道科学会 で，あの器械をみせたら非常に反響を呼びまして，

「これは日本でっくったのか」

「ファイバー・オプティクスは，そして值段は」 といらから，

「日本製だが，アメリカからファイバー・オプティ クスを輸入するので高い」といら話しになったので 
す.

町田 ちょらど同じような色ですし，アメリカでは ライト・ガイドとしてあのころ出していたのは，だい たい 100 ミクロンぐらいの系なものですから，

池田 ライト・ガイドはね.

町田 注い。ですから後のほらで曲げたときに折れ るんですね.

滰野 ライト・ガイドは太いほうが，20ミクロンぐ らいが一番いいとかいら話しを…....

町田 ライト・ガイドとしては，外国の太い系のほ うがどっちかというといいということですね. 50 ミク ロンから20ミクロンぐらいが，20ミクロンぐらいにな りますと，充填率のほうが80\%ぐらいに落ちてくるも のですから，太い糸のほらが效率がいいといらことに なっております。

\section{射出瞳孔による光量}

永島 オリンパスさんのところでは独自で開発をな さっていて，非常なご苦労があって，その結果現在医 学にたい一ん貢献なさっているわけですが，この扔話 しはまたのちほどお伺いするといたしまして，ひとわ たり皆さんの扔話しを伺ったわけですが，いま伺って おりますと，だいたいライト・ガイドとしては非常に いい，汐ども，非常に問題になる解像力の点につ いて，まだ言及をいただいていないよらに思らのです が，そういった点で，中島さん專門的な立場から捄話 しを扔願いします。

中島 実忙こういう問題が出 たときに，これはいいものがで きた.どこまで果してやれるも のかということを考えました。 私出身がレンズ設計なもので すから，第一番に分解能（解像

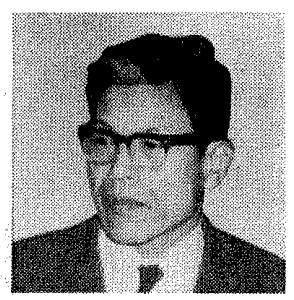
力）のほうへ頭が行ってしまうわけです、それで考え まして，現在の普通の気管支鏡の外径 5 ミリ程度のも ので，視野も40 50度ぐらい，それから解像力が現 在のものとほぼ同じとした時に，単繊維がどれくらい の太さだったらいいだろらといらことを先に計算して みたんです.そうすると，どうしても 3 ミクロンぐら いのものが必要なんです。しかし現在の繊維では，ど らしてもつぶつぶが見える.つぶつぶが見えるといら ことは，実注私非常にそのときに気になりました：光 学系を使ってやればそらいうことはありませんが，こ のぶつぶつはどらにむならんところじゃないかといら ことです．これは一つ，少なくとも5ミクロンぐらい のものができるまで見送ろらじゃないか，ただ，ライ ト・ガイドとしては非常に有效な手段だから，これは
一つ考えようということで，50ミクロンのものを初 め手に入れました．それを曲师るとボ口ボ口折れてし まうんですね. らまくできたと思ってパイプに入れ て，それでしばらく置くと，またボロボロに折れてし まいまして, 半分ぐらいしか残らない.

もら一つは, 初めのころのファイバーは，ご承知の ように，非常に黄色っぽい１メートル半ぐらいにな るとかなり黄色くなってしまら。これじや困るんじゃ ないか.とくにカラ一写真などになりますと, 黄色っ ぽくなってしまいまして，ちょうどこのライト・ガイ ドをやりましたときに，その照明が黄色っぽくなると いらので, 逆に光学系にアンバー・コーティングをや ったものなど非常に青っぽく出ますから，それで補整 できるんじゃなからうかといらことを考えたかけなん です，それをやってみますと，案外色がよく出てくる ものですから，これは一つライト・ガイド専門にしば らく使って，そのうちに町田さんでいい解像力のもの が出るんじゃないかと思って，実は期待しておったわ けです，で，差し当たり私のほうは，いまのところイ メージのほうはあきらめているといらような形なんで 寸㱛，その意味からいいましても，ちょっとあとから 歩いているといら形なんですけれども，思い切って光 学系のほうを明るくして，両方で責めて行こらじゃな いか.イメージのほうは町田さんのほうにお願いして おいて，光学系の明るいものをつくってみようじゃな いかといらことで, 射出瞳孔といらことを光学機械で は申しますけれども, 光学機械を明視距離以上離し て，光りのほうに向けてみますと，接眼鏡の後に丸い 明るい円孔が見えます，これが射出瞳孔で，この孔が 大きいほど反射吸収ということを無視しますと明る い.っまりこの面積に比例して光学系が明るいといら ことになりますので，それをこれ以上明るくできな い.つまりパイプの内径いっぱいにひろげてやる.い いかえれば, パイプの内径そのものが瞳だといらふら な構造のものを作りまして，がり明るいものができ たわけです、ところが久点としては梁度が浅い、レン ズが明るくなれば深度が浅くなるといらことは止むを えないのです.

で，将来もこのイメージのほらをあきらめていると いらわけじゃなくて，現在は見送っているといらわけ なんですけれども，ただ私にいわせていただければ, 解像力を增すためにファイバーを細くすると，光の伝 達效率といいますか，光の透過摔が著しく低隇してく る. それと外の鞘の部分の厚味というものは，原理的 にもある厚さ以下にはできない，そうしますと，ます ます光を通す効率が悪くなってくるといらことで，奏 際使えるものといらのはせいぜい10ミクロンぐらいが 
明かるさと解像力がマッチする限度じゃないかという ような想像なんでございます。

それで, さらにもっと強力な光源が開発されて, 送 る光をうんと強くできれば,ささらに細いファイバーを 使っても十分な光量が得られるのではないかと思いま す.そういう方向を実はわれわれ使う側として望んで いるわけなんです。

それともら一つは，いまのところかなり高価なもの で，故障を起こしたら全部廃衰しなければならない。

これが致命的なものじゃないかと思らのです。

最近ちょっと何かで見たんですが，アメリカの化学 会社のジュポンですか，アクリル樹脂か何か, そうい う采統のもので何か.

町田 現物は見ておりませんけれども。

永岛 それはアクリルのファイバーですか.

中皿 ファイバーで，やっぱり20ミクロンぐらい，

同じょうにやっているんじゃないですか.

近藤 そのほうがいいですか.

町田 相当安いらしいですね.

中岛 安くて折れないらしいです。

滝野 アクリルは橋本教授もちょっとふれられてお られたんじゃないですか.

永岛 それはファイバーじゃなくて棒です。

町田 アメリカで売り出されているのは, ファイバ ー1本がだいたい 200 ミクロン，それを何本か束にし て、それをプラスチックでかためたものらしいですね. ですから1本1本のコーティングがされていないので はないかと思われます。

中岛 そうすると，それはイメージ用としてちゃん とまとめてあるんですか。

町田 いやライト・ガイドですから.

中㘠 実はその考え方を，いまこんなことを申して はおかしいですが, 普通のガラス䋊維でやれるはずだ といらことを考えたわけです，それで，実は表面さえ きれいになれば，単繊維のままで光を完全に伝達する ことができますが，まとめた場合，繊維相互の接触部 分だけが非常に問題になるわけですね. それで接触部 分がどの程度あるか, 繊維間の間隔が 2 分の 1 波長以 上離れていればお互いに交錯することはないはずなの で, 単純な硝子繊維がいまのカバーしたものと同じよ うに使えるんじゃないかといらことを考えまして，実 は日東緔ですか, 向こらで繊維を引張っているという ことを聞きまして，その短かい部分だけをもらえばい いといらことで, 慶応の西端先生にご紹介いただき, 向こうへ行きまして,ファイバーだけを，これはオプ ティクス関係ではなく, 普通の織物に使うやつですか ら実にきたないが，それで短くても実験できるだろう
といいうのでやってみたのです.一応うまく行くので すが，非常にきれいに清掃するといらことができない です权.上ごれていると光がドンドン逃げてしまらで す. 非常にきれいに洗って束ねて，ものすごくかたく しばって，できるだけ接触面積が大きくなるようにし てやってみたんです．それで一応使えるところまで行 くんですが，何しろ短かいものですときれいに清掃で きるんですけれども，長いものですとどうにもだめな んです. 結局コーティングをやらなければだめだとい らことだったのです.

滝野 清掃といら意味はまわりを清掃する.

中岛 そうです.1本1本よごれがつかないように.

滰野 両端さえきれいにしてあったら，まわりはよ ごれていても.

中島 それは普通のコーティングしたものならばい いんですけれども，単繊維では側面が污れていると光 が逃げてしまいますね，そういら点があるのと，それ からもら-つつ，そのときにアクリル樹脂の系が引け ないかといって盛んにやったんです.のちほど化学関 係のことをやっていた者聞いたら，アクリルという ものは糸が引けないといらことをいわれまして，これ もやはりだめだということであきらめたような事情な んです.

\section{イメージ・ガイドと細さの限界点}

池田 先ほどファイバーの繊維の太さをおっしやっ ておられましたけれども,グラスファイバーの文献と いうのが，最近私知らないんですが，前们調べました ときは非常に少ないんです. その文献の中で見ました のでは, 10 ミクロン以下であると光りの遇減率が非常 に大きい，といらふらに読んだのを覚えております。 できるだけ全体のまとめを細くするためには，1本 1 本を細くしなければならない，それで，さっき町田さ んがいわれた，㯰くとふわっと下へおっこちてこない といらのは, 最近使っている12ミクロンのやつなんで すが，先ほどちょっとふれました 7 項目といら項目の 中に，「10ミクロン以下にしてほしい」ということを 書いたことがあるんです。それは 5 ミクロンというこ とを想像していたわけです。

これはなぜかといいますと，先ほど中島さんがおっ しやったような解像力の点から, やはり 3 ミクロンと いらのはちょっときついなと思いますけれども，せ いぜい 5 ミクロンぐらいにしたい、けれども, 遁減率 の問題が非常に大きく問題になっておる. しかし最近 の文献ではないですが，実際のものを見てみますと， 5ミクロンでも太さのまとまりさえよければけっっこ 55 ミクロンの光源の光量の违減は畺くないというこ 
とをいっております，そういう意味で，できるだけ細 いものを使らということが望ましいのではないか.こ れはイメージ・ガイドの終局点じゃないですか. これ が将来の問題にかなりひっかかってくるんじゃないか と，そらいらように私は感じております。しかし，い まおっしゃったように，つくる上においてまだまだ先 があると思います、しかし，ある程度の細さで気にさ れておる，いまの黑い点は 1 枚のスナップの写真では 目につくんです、ところが映画にしますと，その黒い 点が動くわけです，それで目にらつるイメージとして はきれいに写るわけです，ですから案外きれいに，さ っき中島さんが扔っしやったのは，スナップだからき たないんで，撮られた映画を見れば，西あこんなにき れいかな，と思う．それで，使うほうでスナップを撮 らないで映画を撮るよらにすれば，いまのそんな太さ にこだわってっくってもらわないよりは，っくってい ただいて使わせていただいたほうがいいと思うので す. 4 ミクロンぐらいまでにすると，レンズの解像力 とだいたい同じくらいになるといら文献があるんじや ないですか.

中岛それは全体の太ささえかまわなければ，現在 のままでも非常に解像力をあげることができるといら ことはいえるんです亦．初めに抎大して，それから縮 小して受けるといらことにすれば，たとえば20ミクロ ンを使っておりましても，逆に 3 倍でやりまして，そ れから 3 分の 1 に縮小寸れば 9 分の 1 の荒れになるん です. 略々 2 ミクロンのものを使ったと同じ効果が出 るといらことがいえるわけです，ですから，ある程度 広い範囲をいっぺんに見たい，それから倍率もある程 度ほしいということになると,どうしても両立しなく なるわけです.

潼野 私も胃鏡をやったことがあるんですが，たし 肌胃鏡検查は視野が広いです。したがって，これは 光量もいるし，また視野角度も広くなければならない し，深度も梁くなければならない，しかし気管支鏡な り，食道鏡，耳鼻咽喉科領域ではあれほど広くありま せんからね.ことに曲がりくねった先の先までという ことになれば，きわめて短い距離を見るだけのことで 寸から.

\section{使用目的で異なる太さの許容度}

中岛だからこれは，使用目的によって選択して行 くといらことしか，現在のところしょうがないと思ら のです.

近藤 どれくらいの太さがいいかね.

中岛これは場合によれば少し太くしてでも広角を 見る，あるいはこまかいものを，とにかく見たい視野
をある程度詰めてもいいというようなことですね。

滝野 それで胃鏡と気管支，食道，あるいは耳鼻科 領域と太さはいいあんばいになっている．胃鏡のほう はある程度太くしてもいいわけですね.

中禹そうですね. ですから，ちょうどそれが並行 しているんですね，矛盾はしていないわけです．

近藤 太さには，わりに制限がありませんから．

池田 それからもう一つ問題点というのは, 先端の かためですね.そこに胃関係のと，それから気管支関 係，食道関係，それからさらに今度細く必要とする分 野, たとえば必业器分野とか, それから将来立だまだ いろいろの分野とか，たとえば心臓の問題とか，もち ろん十二指腸とか，ずうっと奥のほうまで行くと思い ますけれども，そらいう分野にも関係があると思いま す、先端のかためをできるだけ短くするということ， 先ができるだけ多く曲がるということになる．胃につ いては割り合い長くても決してかまわないです.

近藤 現実に使うと，それが 2 ミリ， 3 ミリ違えば もうたいへん違ってくるわけですね。ですから結局は ライト・ガイドにして，先をうんと短くする．太さの ほうは，胃鏡ではあまり問題ないですからね。

滝野 文献に上れば，1958年にアメリカでは 3 ミリ のをつくっておりますね. 泌尿器用のもので, 気管支 の細い部分をみている．ただあれは見たといらだけの ようですが…...

町田 心臟のほうも文献には出ておりますね. あれ は片方イメージで，片方ライト・ガイドですね.

滝野 アメリカでも 3 ミリをつくっているのですか ら, いま 5 ミリしかつくれないといらのでなしに, 優 秀な日本の技術で， 3 ミリのものをつくったら……

町田 2 年前に 2.8 ミリといらのをつくりまして, 一応使ってみていただいたのですけれども, 使用の際 の強度の点で，まだ自信がありません，

潼野 どの程度に見えたかという，そういう試みは みんなの願らところですね.

町田 たしかに細くして行かなければいけないです が，だいたいアングルだとか，ほかの操作というもの が必ずつきまとってくるので…....

滝野 それが少しぜいたくなんです权、（笑）

池田 先ほどから町田さんにさんざんそれをいわれ るんですがね.（笑）私が当初出しましたのはものす ごくきついほうです.それで，どらせこんなに行きっ こないと…...

中島でも，これは進歩のためには必要だといらこ とですからね.

池田 それで，これは何でもこうくにゃくにゃ曲が ればいいといらことで，5ミリといらことになったん 
です，をれからだんだん，次から次へときつくせめて 行

中島 可能性と要求が食い違う場合がありますが ね. 原理的にどうにむならんといらところがありま す.それのどこで折れあって採るかといら問題です. それはやはりしょっちゅらつつかれつつかれ，あるい は「こんなのができました」といって見ていただく ということにして行かなけれ代しよらがないんじやな いでしょうか。

滰野まあ一寸刻み五分刻みでもいいですから，少 しずつ前進して行くといらことでしょうね.

\section{ピッチのこまやかさも解像カに影響}

永岛 オリンパスさんのところでは，同時に，この グラスファイバーの開発を研究していらっしゃるとい らことでありますが，いむの皆さん方のお話しを最後 に敷延していただいて，お話しをしていただければと 思います。

霜島 オリンパスという会社 は性格がありまして，よその技 術は買わないで，自分独自で開 発しよらといらいい点もあるん です、ただし，反面，その逆の 点もそれに伴ってございますけ

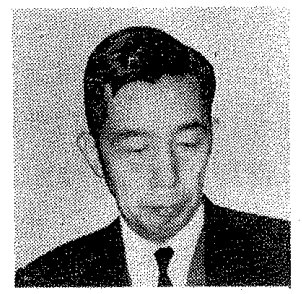
れども，それでファイバースコープに関しましては， それが成功した例じゃないかと思いすす，光学屋とい うのは非常にいい光学ガラスをしょっちゅら使ってお りますので，材料として唀明度の非常にいいものを 使いやすい立場にあります。したがいまして，われわ れに関しては，先ほどから括話しのありましたよう な，透明度のことで苦労したことはないんです。

てれから，さっきアクリルの扔話しが出ましたけれ ども，プラスチックはどらもだめのよらです称.アメ リカで最近いいのができたといらことが新聞に出てい たんですけれども，あれは安いのが特色で，われわれ のファイバースコープにはむりじやないかという，見 たわけじゃないですけれども，艺んな気がします。

それから，細さの点ですけれどむ，まあ 5 ミクロン と10ミクロンの間ぐらいが限度じやないかといら気が するんですね、以まのところもらろんそこまで行きま せんけれども，10ミクロン以下のものが，アメリカの AOCあたりで試作されているよらですね.

それからもう一つは，繊維の細さ之同時にピッチが 大切だと思いますね。ですから綮密にいえば，㵶維の 細さがいくら細くたって，ピッチが荒かったら解像力 が悪いんですから，むしろ瀻維の細さといらことと同 時に，ピッチの細かさといらことを考えるい゙きじやな
いかと、もちろん細くして，同時にピッチが小さくな るのが一番いいと思らのですが。

永島 もちろん括たくではグラスファイバーは搔つ くりにならないわけでしょら…...

霜島 らちの会社では材料は買ってきますけれど む，ファイバーは全部つくって招ります。ですから， いま括話しのありました，日本硝子繊維さんがやって いるようなことは社内で一応やって招ります。

潼野 光学ガラスといらのと普通のガラスといらの は本質的に違らんですか，純度が違らといらことです 加.

霜島 純度が違うといったほうがいいかもしれませ ん. 本質的には，ガラスといら一種のあるいう無機物 質の点では変わりありむせん，純度とか，透明度と か，屈折率を非常にらるさくいいます。そらいら点が 非常に普通のガラスと違うんです。

潼野わかりやすくいえば，光学に使えるようなガ ラスといら意味ですね.

霜島 その通りです。

滝野 それから，先ほどの「ピッチ」といらのは。

永島 繊維が立んでおります社。その中心から中心 八の距離ですね.

近藤、密度といってもいいですかね. ちょっと違う んですか。

霜島 そらです，繊維の中心から次の繊維の中心ま での距離をピッチといったのです。

滝野それが荒いといらのはどういうことですか。

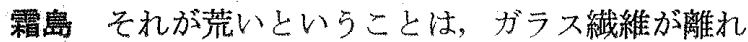
るといらことです。

潼野 いい換えれば，詰めればギューっとピッチ

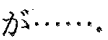

霜息 小さくなります。

潼野，その技術は……

\section{外国を凌駕する日本のまとめる技術}

中島 まとめ方のうまい，へたといらことになりま すか。

町田 普道は充填率といら言葉で現わします，充覑 率がよくても，繊維の外径は10ミクロンでも，コーテ イングの厚味が厚いと，ピッチは同じになりますが, 光量的にロスが多くなります。

近藤 ピッチはコーティングの厚さに関係ないので すか?

町田 外径が同しとすればですね。

潼野ただ，光が通って行く中身の問題 Core です 就。

滰野 いつか町田さんがいわれたですが，特許を取 
らないでいいのですか. その技術は日本とアメリカと 比べて，日本のほうが進歩しているんですか.

町田 日本人の手の器用さを利用することで, いろ いろな方法が取り入れられております。

近藤 ハーショウィッッのほらがずらっと本数が多 いでしょう。

町田 ええ, 15 万本はいっているといわれており ますね。

近藤 公称はね.

町田 充填率としては，ハンショウィッッのものは 相当いいですけれども，製法が違うのではないかと思 います.

近藤 世界消化器学会で，町田製のファイバー胃鏡 に心から感心した人々が第一に発する質問は，これは どれ位の細さのものが何本束ねてあるかということで した．答えてやりますと，それでどらしてこんなにイ メージがいいんだと驚いていました。私はちっとも理 由がわからないから，実際見ればいいんじゃないか と，こういうよりしょうがないんでね.

町田 像のくずれですね.

滝野 くずれといらのは配列の仕方ということです 力.

町田 先端と後端との采のくるいです.

滝野 位置が同じならばいいということですね。

町田 必ず同じなら泣，それが最良のものになるの です.

潼野 その技術が日本はいいから，本数が少なくた って解像力はよい。

町田 そうですね. 直線を見ますと，向こうのも解 像力はすごくいいのですが，血管を見ますと，網のよ らに見える時があります。

池田 それからもら一つ問題点として，1本のファ イバーの均等性といらのですか，こっち側の面とこっ ち側の太さがもし 5 ミクロンというと，もうちょっと の狂いで違うはずでございますから，これは相当大き な解像力に問題があるんじゃないですかね.

町田 像がゆがみます。

池田 ええ.これが細くなればなるほど問題になっ てくると思います.たしかキャノンで 5 ミクロンのフ アイバーを試作したはずなんですが，これは去年の初 めに私見ておりますが，これがいまいったような意味 で失敗しております，像の均等性がないものですか ら，実際的には使えない５ミクロンにつくりました がだめだということになったです。

\section{角型と丸型の長所, 短所}

中岛それから最近，6角とか4 角いやつがぼつぼ
つ出はじめてきたといらことを文献抄録で見たのです が.

町田 $\mathrm{AOC}$ O ジは，36本が一本の4角のファイバーになって，それ をまとめてあります.

霜岛 まとめて，それが4 角だとか，6角だという 意味ですか.

中岛 いや，繊維そのものが 4 角とか 6 角といらこ とで，まとめる時に，同じ太さでも効率がよく，解像 力もいくぶん上がるんじゃないかといら気がするんで †.

町田 高さと横の詥差がほんのわずかあっても, 丸 のものより並べるのがむずかしくなるのではないかと 思います.

中岛 6 角になると.

町田 6 角でも 4 角でも.

中岛 丸でないとだめですか？

町田 丸のほうがなじみがいいという…....

滰野 角があるより丸い方がやっぱり。（笑）

町田というような話しを聞いております.

中岛われわれは鉛筆を束悋るつもりでおりますか 5.

町田 それから，4角いファイバーにもら一ついえ ることは，使っているときの切れの問題があると思い ます. 丸の場合は一番そういうときの摩摖は少ないわ けです，実をいいますと，AOCのイメージを使いま して,ファイバースコープをつくったことがあります が，非常に切れやすくて実用にはなりませんでした.

\section{普及度と製造法の合理化}

潼野 值段が高いということ．これは何とか安くな らないでしょうか，というのは，普及率というのは， やっぱりその值段に関倸すると思うのです，きれいに 見えるんですから, 安ければ従来の電球によるテレス コープと同じ程度に普及して行くものだと思うので す.この点はどうなんでしょう. 見通しとしてやはり 高いものなんでしょらか。

近藤 沢山使えば安くなりますよ.

滝野 そうでしょらか. そこが問題なんですが.

町田 糸のほうは私にはわからないので.

中岛 普通のガラスに比べて量的にも微々たるもの ですからね. それともう一つは，稀少価値として下げ ないんじゃないでしょうか.こんなことをいっては悪 いんですけれども.

霜岛 たくさん使われるようになって，それから製 造法も考えられてくれば, 将来はもっと安くなる可能 性があると思います。ただ現在は，これは会社によっ 
て違いますが，研究投資をたくさんして，それでどの くらいの見通しがあるか，まだ正直のところわかりま せんので.......

滝野 やはりご商売ですからね.

霜岛 検查も敛重ですし，アフターサービスもしつ かりやる必要があり，そういう関係でああいう值段が ついているわけで，決して現在の時点ではぼろもうけ しているわけではございません.

滝野 器械屋さんのほうでは，グラスファイバーが 高いから高いんだということなんですが…....

永岛 これからグラスファイバー屋さんのほうをせ めることにいたします（笑）

池田 それともら一つ大きな問題として，1本 1 本 も高いけれども，それをつくる過程において，壊れや すい. それからつくったあとで壊れやすいといら，そ れが高くなる大きな…...

近藤これは買う人が全部最初に考えます极。

中岛 私はこういうことを考えてみたことがあるん です.たとえば，内部を無機ガラスでやって，さやを 有機ガラス，つまりプラスチックでこしらえたらどう だと．吹きつけでずらっと通して，そらして乾燥した
やっを巻き取って，できないもろだろらかと思ったこ とがあるんです，そうしますと，これは想像ですけれ ども…...

町田 有機質のコーティングは, A OCOパテント の中に書いてあるのを見たことがあります.

中岛 そうするともっと強くなりはしませんか.

町田 さあ，らちでは扱ったことがないので……

中禹 かなり安価なものになりそうですね. プラス チックになりますと.

滝野 日本の得意とするレンズ系で，ああいうフレ キシブルのむのはつくれないですか.

中岛 Wまの軟性の胃鏡以上のものはどらもむりだ と思います. どうしても太くなるんですね.

滰野 細くてはだめですか.

中岛細くてはすぐ視野が久けてしまらわけです。

滰野 やっぱりむりなんですね.

永岛 いろいろ貴重なお話しをありがとうございま した.もっと括話しを伺いたいんですが，時間もだい ぶん経過いたしましたので，一応これをもって座談会 を終わることにいたします，どうも皆さんありがとう ございました。

\section{呼吸器疾患は吸入療法で良く治る}

\section{星英米岩并式ネブライ ザー}

日本特許 $228983 \sim 5$

英国特許 $\quad \begin{array}{llllll}9 & 1 & 6 & 1 & 9 & 6\end{array}$

米国特許 US 28771855

マイシン・種々の新薬を 0.1 ミクロンの極微 粒煙霧として肺胞まで吸入し，直接殺菌治療 するので，浸潤・空洞は萎縮消失してきれい に良く治ります.

耐性のついた方は，厚生省製造販売許可の 特許岩井式油脂吸入機と薬油ゴマカプリン酸 で良く治ります.

本機使用料として薬を別として健康保険よ り 6 点請求できます.

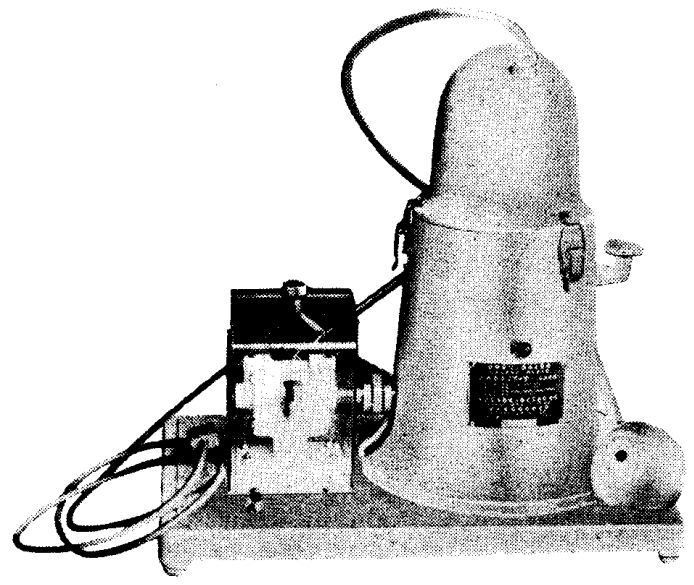

多忙につき取次店求む. 医師優先!

説明書希望者は郵券20円封入お申込み下さい。

\section{岩井式油脂吸入機株式会社 \\ 岩井油脂物 療 研究所}

横浜市神奈川区旭ケ丘 60 番地 電話神奈川 (48) $5941 \sim 3$ 